\title{
Cancer detection ratio in a population participating in cancer screening programs at a tertiary care cancer center in São Paulo
}

\author{
Diego Fernandes dos Santos, Maria Paula Curado ${ }^{1,2,3^{*}}$ and Diego Rodrigues Mendonça e Silva ${ }^{2}$
}

\begin{abstract}
Background: Tertiary care cancer centers can act as reference units for prevention and early detection programs. The purpose of this study was to describe the profile of the Cancer Prevention Campaign (CPC) participants at the A.C. Camargo Cancer Center in Sao Paulo, Brazil.

Methods: A cross-sectional, quantitative study was carried out to analyze data of the CPC participants at the A.C. Camargo Cancer Center. Participants were recruited from the general public during lectures delivered by CPC members in selected parts of the city of São Paulo. Data included gender analysis, number of cancer cases diagnosed, topography and tumor/node/metastasis (TNM) stage, in the period 2008-2012.

Results: Sixty-two thousand nine hundred one people participated in CPC during the 5-years period (2008-2012). A total of 65 cancer cases were diagnosed, which represents $0,1 \%$ of detection rate: 25 cases were identified in men and 40 in women. The most frequent neoplasms in men were thyroid, prostate and oral cavity cancers while in women, thyroid and breast cancers were more frequent.

Conclusions: Cancer prevention activities in tertiary care cancer centers raise awareness in its employees and in the general population, increasing early diagnosis.
\end{abstract}

Keywords: Early diagnosis, Cancer prevention

\section{Background}

In 2012, more than 14.1 million new cancer cases were estimated globally, with approximately 8.2 million deaths [1]. These estimates indicate that there will be approximately 20.3 million new cancer cases in the world in 2030, with 13.2 million deaths [2]. In Brazil, estimates of the National Cancer Institute (INCA) indicate 596,000 new cases in 2016 and 2017 (including non-melanoma skin cancer). The most incident cancers (excluding nonmelanoma skin cancer) in men will be prostate $(61.82 \%)$, lung (17.49\%), colon and rectum (16.84\%), stomach (13.04\%) and oral cavity (11.27\%) cancers. In women, the most frequent types of cancer will be breast

\footnotetext{
* Correspondence: mp.curado@cipe.accamargo.org.br

${ }^{1}$ Graduate Program in Science, Antônio Prudente Foundation, A.C. Camargo Cancer Center, São Paulo, Brazil

¿Epidemiology Department, International Center for Research and Education, A.C Camargo Cancer Center, Rua Tagua, 440, Liberdade, São Paulo CEP: 01508-010, Brazil

Full list of author information is available at the end of the article
}

(56.20\%), colon and rectum (17.10\%), cervix (15.85\%), lung (10.54\%) and stomach (7.37\%) [3].

Given the increasing incidence of cancer cases, the role of tertiary care cancer centers as providers of treatment and cancer control strategies can become an important instrument in the reduction of mortality, due to the capacity and experience in identifying and treating initial/early cases [4]. Although tertiary care cancer centers have been active in the prevention area in developing countries, there is limited knowledge on the role of these units in screening risk populations.

Screening was defined in 1951 by The Commission Conference as "the presumptive identification of unrecognized disease or defect by the application of tests, examinations, or other procedures which can be applied rapidly and sort out apparently well persons who probably have a disease from those who probably do not" [5]. According to Public Health England, the criteria that currently evaluate viability, effectiveness and adequacy of 
screening programs are: reduction of mortality and morbidity, acceptable diagnosis and treatment procedures. The benefits gained by individuals must outweigh any harms, and the cost-benefit-effectiveness must be also considered [6].

Screening programs are characterized by a high number of asymptomatic people submitted to one or more previously established tests to detect cancer in pre-clinical stages. The main reason for diagnosis in preclinical stages is to begin early treatment of the disease [7]. Effectiveness of screening reflects changes in the detection of cancer in its initial stage, which reduces incidence and mortality in the population screened [8]. Screening can be classified as organized or opportunistic. In organized screening, actions are systematized to detect neoplasms in an asymptomatic population, identifying the target population through a regular call for participants. In opportunistic screening, or unorganized screening, clinical evaluations are carried out in the participants without any monitoring of the steps, which span from recruitment of risk population until adherence to convocation [9]. A North-American study, carried out at the Dwight D. Eisenhower Army Medical Center in Georgia between 1995 and 2000, investigated the impact of prostate cancer screening in Afro-American men and in those with prostate cancer history in the family, aged between 40 and 75 years of age. In this tertiary center, prostate cancer detection rates were $0.7 \%$ in 6 years [10].

A tertiary center in India compared the age of women with cervical cancer with data from Surveillance, Epidemiology, and End Results (SEER) and verified that cervical cancer in India was more incident in women with average age 50 years old $(71.5 \%)$, while in the USA the average age was $48(16.8 \%)$. The lack of screening programs in India hinders cervical cancer diagnosis, which occurs mostly in women over the age of 45 [11].

One of the first screening programs for cervical cancer in Brazil took place in the state of Sao Paulo (Southeast Brazil), in the city of Campinas; in 1968, approximately $85 \%$ of diagnosed cases were stages II, III and IV. After the implementation of the screening program, there was an increase of approximately $86 \%$ in intra-epithelial neoplasia diagnoses and only $3 \%$ in stages II, III or IV [12]. In the city of Goiania (Midwest Brazil), the results of opportunistic screening verified a decrease of $33 \%$ in mortality rates [13]. TNM prostate cancer staging was carried out by the Mobile Unit of Cancer Prevention (Unidade Móvel de Prevenção de Câncer - UMPC) of the Barretos Cancer Hospital (Hospital de Câncer de Barretos - HCB) after screening 17,571 men over 45 years of age: $75 \%$ of identified cases were stage I, while $23.2 \%$ atn BCR were stage I [14]. Studies of the U.S. Preventive Service Task Force (2012), Cochrane Collaboration (2013), and National Health Service (NHS) (2010) corroborate on the limitations of screening practices for prostate cancer. In Brazil, INCA does not recommended screening for prostate cancer, however there are guidelines for breast and cervical cancers [15].

Biennial mammographies are recommended for women in the age group 50-59 years old for early detection of breast cancer [16]. For cervical cancer, the cytopathological test is recommended for women aged 25-64 years old, every 3-years after two normal consecutive annual tests [17].

The Brazilian Society of Coloproctology, INCA and the Brazilian College of Surgeons recommend screening programs for colorectal cancer. Low-risk individuals should be tested for Fecal Occult Blood (FOB) after the age of 50 and undertake rectosigmoidoscopy every 5 years. After the age of 60, colonoscopy or opaque enema should be carried out every 10 years. For high risk individuals, over the age of 50, with family or personal history of polyps and/or intestine cancer, ulcerative rectocolitis, Crohn's disease, or breast, ovarian or uterine cancers, it is recommended to begin screening at 40 years of age, including colonoscopy [18].

The A.C. Camargo Cancer Center is a tertiary care cancer center, which also encompasses preventive and screening activities. The creation of the Cancer Prevention Campaign (CPC) in 2007, has strengthened the interest of the A.C Camargo Cancer Center regarding cancer prevention activities in cancer. The strategy of the CPC is to perform opportunistic actions, recruiting participants from the general public during talks and lectures on cancer awareness in churches and squares of São Paulo.

The study presented herein describes the detection ratio of cancer within the Cancer Prevention Campaign at the A.C. Camargo Cancer Center, and identifies the most frequent cancer sites diagnosed in the period of 2008-2012.

\section{Methods}

A cross-sectional, retrospective study abstracted data from CPC participants between 2008 and 2012. Selected variables were analyzed, including gender, age, topography and clinical TNM stage [19] of the cancer cases diagnosed.

The following neoplasms were screened: melanoma and non-melanoma skin cancers, and oral cavity, breast, lung, colon, testicular, prostate and cervical cancers.

Routine activities at the CPC include physical examination of all participants. Laboratorial tests for all participants are shown in Tables 1 and 2. This project was approved by the Research Ethics Committee of the Antonio Prudente Foundation at the A.C. Camargo Cancer Center, and registered under protocol number 1889/14, May/2014.

\section{Results}

A total of 62,901 participants were registered at the CPC in the A.C. Camargo Cancer Center, in the period 2008-2012. 
Table 1 Routine tests requested to the $C P C^{a}$ participants at A.C. Camargo Cancer Center

\begin{tabular}{|c|c|}
\hline Men and women (all ages) & \\
\hline Blood Tests & (continuation) Blood Tests \\
\hline Uric Acid & $\begin{array}{l}\text { Glycemic Hemoglobin and } \\
\text { Estimated Glucose }\end{array}$ \\
\hline Amylase & Hepatitis B (anti HBC Total) \\
\hline Total Anti-HAV (lgG) & Hepatitis B (anti HBs) \\
\hline Total Anti-HAV (IgM) & Hepatitis C (anti HCV) \\
\hline Anti-globulin & LDL Cholesterol (calculated and dosed) \\
\hline $\begin{array}{l}\text { Bilirubin (Total, Indirect, } \\
\text { and Direct) }\end{array}$ & Magnesium \\
\hline Calcium & Potassium \\
\hline Chlorine & $\begin{array}{l}\text { Total Protein and Fractions } \\
\text { (Total, Albumin, Globulin, Ratio) }\end{array}$ \\
\hline Total cholesterol & White Series \\
\hline Platelet Count & Red Series \\
\hline $\begin{array}{l}\text { Creatinine (+ Afro and Non } \\
\text { Afro Descending) }\end{array}$ & Sodium \\
\hline Rh Factor & T3 \\
\hline Ferritin & T4 \\
\hline Iron & Free T4 \\
\hline Alkaline phosphatase & $\begin{array}{l}\text { GOT (Glutamic-Oxaloacetic } \\
\text { Transaminase) }\end{array}$ \\
\hline Phosphor & $\begin{array}{l}\text { GPT (Glutamic-Pyruvic } \\
\text { Transaminase) }\end{array}$ \\
\hline GT range & Triglycerides \\
\hline Glucose & TSH (Thyroid-Stimulating Hormone) \\
\hline ABO Group & PT (Prothrombin Time and Activity) \\
\hline $\mathrm{HBsAg}$ & PTT (Partial Thromboplastin Time Activated) \\
\hline HDL Cholesterol & Urea \\
\hline Men (40 years or over) & Women (50 years or over) \\
\hline Urine type I & Papanicolaou \\
\hline $\begin{array}{l}\text { Total and Free Prostate } \\
\text { Specific Antigen (PSA) }\end{array}$ & Mammography \\
\hline
\end{tabular}

${ }^{a}$ Cancer Prevention Campaign/A.C. Camargo Cancer Center

Sixty-five cancer cases were diagnosed, which represents $0.10 \%$. In 2008, the first year of the CPC, the campaign had 5,473 participants, of which $0.16 \%$ were diagnosed with cancer (Table 3).

Of the 65 confirmed cancer cases in the period 20082012, the most frequent neoplasms in men were thyroid $(6 / 25)$, prostate $(5 / 25)$ and oral cavity cancers $(5 / 25)$. In women, the most frequent types of cancer were thyroid $(23 / 40)$ and breast $(9 / 40)$ cancers.

Regarding TNM staging, seven out of 25 cancer cases in men were stage $0 / \mathrm{I} / \mathrm{II}$ and nine out of 25 were in advanced stages (III/IV). In women, 20 were in initial stages, and seven were in advanced stages (Table 4) [20].

In the first semester of 2016, updated information on complementary imaging tests versus post-first consultation
Table 2 Complementary exams requested after first consultation at $C P C^{a}$

\begin{tabular}{ll}
\hline Exams & \\
\hline Colonoscopy & Magnetic Resonance Imaging \\
Endoscopy & Tomography \\
Biopsy & Ultrasonography \\
Scintigraphy & Colposcopy \\
Mammography & Pap smear (Papanicolaou) \\
X-ray & $\mathrm{FOBT}^{\mathrm{b}}$ \\
\hline
\end{tabular}

${ }^{a}$ Cancer Prevention Campaign/A.C. Camargo Cancer Center; ${ }^{b} \mathrm{Fecal}$ occult blood test

imaging tests at CPC demonstrated the frequency of exams requested to CPC participants o (Table 5). With 4,358 requests for ultrasonography tests, it was the most common test requested during $\mathrm{CPC}$, out of 13,523 medical tests $(32,2 \%)$.

\section{Discussion and conclusions}

Screening unit activities in a tertiary care cancer center can play an important role in the prevention and early detection of cancer. These activities can support organized screening programs in collaboration with the public health system. During the Cancer Prevention Campaign $(\mathrm{CPC})$ at the A.C. Camargo Cancer Center the detection ratio of cancer ranged from $0.01 \%$ to $0.29 \%$ in the studied period (2008-2012). The percentage of cancer diagnoses by tertiary centers engaged in prevention and screening policies varied from $0.1 \%$ for colorectal cancer [19], to $0.7 \%$ for prostate cancer [15] and $10.7 \%$ for skin cancer [21].

When screening, the main objective is early diagnosis; when preventing, the objective is to educate on

Table 3 Percentage of cancer cases detect at CPC ${ }^{a}$ between 2008-2012, São Paulo, Brazil

\begin{tabular}{lll}
\hline Year/Participants & Total & $\%$ \\
\cline { 2 - 3 } & $n$ & 100 \\
\hline 2008 & 5473 & 0.16 \\
Cancer cases & 9 & 100 \\
2009 & 6893 & 0.23 \\
Cancer cases & 16 & 100 \\
2010 & 5082 & 0.29 \\
Cancer cases & 15 & 100 \\
2011 & 12,179 & 0.17 \\
Cancer cases & 21 & 100 \\
2012 & 33,274 & 0.01 \\
Cancer cases & 4 & 100 \\
Total 2008-2012 & 62,901 & 0.10 \\
Cancer cases & 65 & \\
\hline
\end{tabular}

${ }^{\mathrm{a}}$ Cancer Prevention Campaign/A.C. Camargo Cancer Center 
Table 4 TNM staging of cancer case detected by the CPC ${ }^{\text {, }}$, between 2008-2012, São Paulo, Brazil

\begin{tabular}{|c|c|c|c|c|c|c|c|}
\hline Topography & 0 & I & $\|$ & III & IV & $N / A^{b}$ & Total \\
\hline \multicolumn{8}{|l|}{ Men } \\
\hline Bladder & 1 & & 1 & & 1 & & 3 \\
\hline Oral cavity & & 1 & & & & 4 & 5 \\
\hline Nasal cavity & & & & & 1 & & 1 \\
\hline Colon and rectum & & & & 2 & & 1 & 3 \\
\hline Gastric & & & 1 & & & 1 & 2 \\
\hline Prostate & & 1 & 1 & & & 3 & 5 \\
\hline Thyroid & & & 1 & 1 & 4 & & 6 \\
\hline Total & 1 & 2 & 4 & 3 & 6 & 9 & 25 \\
\hline \multicolumn{8}{|l|}{ Women } \\
\hline Cervix & 1 & & & & & & 1 \\
\hline Esophagus & & & & & 1 & & 1 \\
\hline Non Hodgkin Lymphoma & & & & & & 1 & 1 \\
\hline Hodgkin Lymphoma & & & & & & 1 & 1 \\
\hline Breast & & 3 & 4 & 2 & & & 9 \\
\hline Pancreas & & & & & 1 & & 1 \\
\hline Parotid & & & & & & 2 & 2 \\
\hline Thyroid & & 12 & & 2 & 1 & 8 & 23 \\
\hline Kidney & & & 1 & & & & 1 \\
\hline Total & 1 & 15 & 5 & 4 & 3 & 12 & 40 \\
\hline
\end{tabular}

TNM classification of malignant tumours [20]

${ }^{\mathrm{a}} \mathrm{N} / \mathrm{A}$ Not available

${ }^{\mathrm{b}}$ Cancer Prevention Campaign/A.C. Camargo Cancer Center

preventable risk factors, such as the consumption of tobacco $[9,22]$. The objectives of the CPC at A.C.CCC were to educate (raise awareness) towards an enhancement of early diagnosis in opportunist screening activities.
In $2008,48.2 \%(2,637)$ of CPC participants were men. Participation of men varied from $40.8 \%$ (193) in skin cancer screening in the U.S.A. [23], to $44.5 \%$ (195) for oral cavity cancer screening in Malaysia [24], to $47.3 \%$ $(1,444)$ [25] for oral cancers screening in Brazil. Such

Table 5 Number of complementary exams after first consultation at CPC ${ }^{a}$ in the first 6 months of 2016

\begin{tabular}{|c|c|c|c|c|c|c|c|}
\hline Prevention & January & February & March & April & May & June & Total \\
\hline Patients Attended & 2186 & 2881 & 3353 & 3338 & 3499 & 3309 & 18,566 \\
\hline \multicolumn{7}{|l|}{ Exams pos consultation } & Total \\
\hline Colonoscopy & 108 & 155 & 144 & 139 & 13 & 129 & 688 \\
\hline Endoscopy & 65 & 68 & 83 & 116 & 45 & 113 & 490 \\
\hline Biopsy & 45 & 48 & 20 & 70 & 3 & 23 & 209 \\
\hline Scintigraphy & 1 & 0 & 2 & 1 & 0 & 0 & 4 \\
\hline Mammography & 182 & 131 & 41 & 245 & 75 & 181 & 855 \\
\hline X-ray & 16 & 22 & 8 & 26 & 4 & 27 & 103 \\
\hline Magnetic Resonance Imaging & 25 & 18 & 1 & 27 & 6 & 7 & 84 \\
\hline Tomography & 58 & 39 & 9 & 98 & 47 & 146 & 397 \\
\hline Colposcopy & 37 & 34 & 40 & 46 & 11 & 17 & 185 \\
\hline Pap smear & 59 & 148 & 125 & 173 & 54 & 108 & 667 \\
\hline $\mathrm{FOBT}^{\mathrm{b}}$ & 741 & 895 & 1066 & 1251 & 269 & 1,081 & 5303 \\
\hline \multicolumn{7}{|c|}{ Total Geral Exams after consultation ${ }^{c}$} & 8985 \\
\hline
\end{tabular}

${ }^{a}$ Cancer Prevention Campaign/A.C. Camargo Cancer Center; ${ }^{b}$ Fecal occult blood test; ${ }^{c}$ except ultrasonography 
lower participation, when compared to women, could be related to occupation/professional activities that prevent a more active participation of men in screening programs.

Regarding the frequency of neoplasm detection during the $\mathrm{CPC}$, there were no records on the number of participants according to topography (how many people were screening by each topography during the CPC). This is a limitation of the study, as there is a data gap regarding the number of patients submitted to submitted to complementary tests.

Thyroid cancer (29/65) was the most frequent neoplasm detected in both genders. The reason for such a high number of thyroid cancer cases detected could be related to the number of USG requested by the CPC team (in 2016, USG were requested for $32,5 \%$ of participants). The most frequent types of cancer were breast cancer (9 cases in 40 individuals) in women and prostate cancer (5 cases in 25 individuals) in men. Nevertheless CPC was able to identify the most common types of cancer in its participants, although few cases in early stage The population, although aiming at access to cancer diagnosis and treatment services, can also be seeking CPC for a faster care route.

The CPC A.C. Camargo Cancer Center has been carrying out opportunistic prevention and screening activities since 2008. The results of this analysis describe the practice of opportunistic cancer screening under the leadership of a tertiary care cancer center in a developing country (Brazil). Data presented herein evidenced that CPC was able to diagnose $0.1 \%$ of cancer cases within the recruited participants. A cancer center such as the A.C. Camargo Cancer Center goes further than early cancer detection, raising awareness on cancer prevention and diagnosis in its employees and their families. Due to these activities, employees are better educated on the importance of early cancer diagnosis.

After exhaustive and detailed literature review, no studies were found in Brazilian scientific literature on the experience of screening programs in specialized cancer centers. Therefore the experience of the CPC at the A.C. Camargo Cancer Center can be a reference to new approaches for screening in collaboration with governmental policies and public health institutions.

$\mathrm{CPC}$ can play an important role in the prevention and screening of cancer. However, it is necessary to systematize and organize the role of this center., with the objective of achieving better results in early detection of the most incident malignant neoplasms.

\section{Acknowledgements}

Not applicable for that section.

\section{Funding}

The authors declare that they have no funding.

\section{Availability of data and materials}

The database was created in Microsoft Excel based on records provided by the information technology department.

\section{Authors' contributions}

DFS collected, analyzed and interpreted data, and was a major contributor in writing the manuscript. MPC contributed with the conception of the manuscript, also reviewing and interpreting data. DRMS analyzed data and reviewed the manuscript. All authors read and approved the final manuscript.

\section{Competing interests}

The authors declare that they have no competing interests.

\section{Consent for publication}

Not applicable for that section.

\section{Ethics approval and consent to participate}

The project was approved by the Research Ethics Committee of the A.C. Camargo Cancer Center, Foundation Antonio Prudente, and registered under number 1889/14 on May 14, 2014

\section{Publisher's Note}

Springer Nature remains neutral with regard to jurisdictional claims in published maps and institutional affiliations.

\section{Author details}

${ }^{1}$ Graduate Program in Science, Antônio Prudente Foundation, A.C. Camargo Cancer Center, São Paulo, Brazil. 'Epidemiology Department, International Center for Research and Education, A.C Camargo Cancer Center, Rua Tagua, 440, Liberdade, São Paulo CEP: 01508-010, Brazil. International Prevention Research Institute, Ecully, France.

Received: 8 July 2016 Accepted: 5 May 2017

Published online: 02 June 2017

\section{References}

1. World Health Organization. International Agency for Research on Cancer. Press release 22312 December 2013; cited 2014 Jan 15]. Avaliable from: URL:http://www.iarc.fr/en/media-centre/pr/2013/pdfs/pr223_E.pdf.

2. Ferlay J, Steliarova-Foucher E, Lortet-Tieulent J, et al. Cancer incidence and mortality patterns in Europe: estimates for 40 countries in 2012. Eur J Cancer 2013; Apr;49(6):1374-403. doi:10.1016/j.ejca.2012.12.027.

3. Ministério da Saúde. Instituto Nacional de Câncer José Alencar Gomes da Silva. Estimativas/2016 incidência de câncer no Brasil. Disponível em. http://www.inca.gov.br/wcm/dncc/2015/por-incidencia.asp. [2015 dez 12].

4. Bhatnagar S, Goyal A, Sharma A, Joshi S, Ahmed SM. Journey of patients with cancer: a systematic evaluation at tertiary care center in India. Am J Hosp Palliat Care. 2014:31(4):406-13. doi:10.1177/1049909113494091.

5. Larimore GW, Ryder C. Committee B: early detection and screening. In: Raleigh NC, editor. Preventive Aspects of Chronic Disease Conference Proceedings, March 12-14, 1951. Chicago: Health Publications Institute; 1952.

6. Public Health England (UK). Guidance Criteria for appraising the viability, effectiveness and appropriateness of a screening programme: Public Health England, 2015. [cited 2016 Fev 26] Available from: https:/www.gov.uk/ government/publications/evidence-review-criterianational-screeningprogrammes/criteria-for-appraising-the-viability-effectivenessandappropriateness-of-a-screening-programme\#the-screening-programme.

7. Sloan DA. Rastreamento e detecção precoce. In: Pollock RE, Doroshow JH, Khayat D, Nakao A, Sullivan BO, editors. Manual de oncologia clínica da UICC. 8th ed. São Paulo: Fundação Oncocentro de São Paulo; 2006. p. 139-58.

8. Hulka BS. Screening for cancer: lessons learned. J Occup Med. 1986;28(8):687-91.

9. World Health Organization. Cancer control: knowledge into action: WHO Guide for Effective Programmes; Module 3: Early detection 2007. [2013 Dec 28]. Available from: http://apps.who.int/iris/bitstream/10665/ 43743/1/9241547338_eng.pdf.

10. Soderdahl DW, Hernandez J. Prostate cancer screening at an equal access tertiary care center: its impact 10 years after the introduction of PSA. Prostate Cancer Prostatic Dis. 2002;5(1):32-5.

11. Agarwal S, Malhotra KP, Sinha S, Rajaram S. Profile of gynecologic malignancies reported at a tertiary care center in India over the past decade: comparative evaluation with international data. Indian J Cancer. 2012;49(3):298-302. doi:10.4103/0019-509X.104494.

12. Pinotti JA. Experiência crítica do programa de controle de câncer cérvico- uterino de campinas - Brasil. J Bras Ginecol. 1976;82:461-71. 
13. Almeida FM, Oliveira JC, Curado MP, Junior RF, Moreira MAR. Monitoring the profile of cervical cancer in a developing city. BMC Public Health. 2013;13:563. doi:10.1186/1471-2458-13-563.

14. Faria EF. The study of the screening impacto $n$ clinical staging of patients with prostate câncer [thesis]. São Paulo: Faculdade de Medicina da Universidade de São Paulo; 2010.

15. da Saúde M. Instituto Nacional de Câncer José Alencar Gomes da Silva (INCA). Rastreamento do Câncer de Próstata. Rio de Janeiro: Ministério da Saúde; 2013.

16. Ministério da Saúde. Instituto Nacional de Câncer José Alencar Gomes da Silva (INCA). Coordenação de Prevenção e Vigilância (Conprev). Divisão de Detecção Precoce e Apoio à Organização de Rede. Diretrizes para a Detecção Precoce do Câncer de Mama no Brasil. Rio de Janeiro: Ministério da Saúde. 2015.

17. Ministério da Saúde. Instituto Nacional de Câncer José Alencar Gomes da Silva (INCA). Coordenação de Prevenção e Vigilância (Conprev). Divisão de Detecção Precoce e Apoio à Organização de Rede. Diretrizes para a Deteç̧ão Precoce do Câncer do Colo do Útero no Brasil. Rio de Janeiro: Ministério da Saúde. 2015.

18. Oselka G, Bin FC. Diretrizes em foco. Rastreamento para câncer colorretal. Rev Assoc Med Bras. 2002;48(4):275-96. doi:10.1590/S0104-42302002000400020.

19. Perez RO, Proscurshim I, Julião GPS, Picolo M, Gama-Rodrigues J, Habr- Gama A. Screening of colorectal câncer in a Brazilian town: preliminar results. ABCD Arq Bras Cir Dig. 2008;21(1):12-5.

20. Sobin LH, Gospodarowicz MK, Wittekind C. TNM Classification of Malignant Tumours, International Union against Cancer. 7th ed. UK: Wiley-Blackwell; 2009

21. Lages RB, Barbosa PB, Almeida IP, Lopes LRS, Lopes Filho LL. Early detection of skin cancer: experience of a skin cancer prevention campaign in Piauí-Brazil. Rev Bras Promoç Saúde. 2012;25(2):221-7.

22. World Health Organization. Health in 2015: from MDGs, Millennium Development Goals to SDGs, sustainable development goals. 2015. [2016 Jan 12] Available from: http://apps.who.int/iris/bitstream/10665/200009/1/ 9789241565110_eng.pdf?ua=1.

23. Andrulonis R, Secrest AM, McGuire ST, Geskin LJ, Ferris LK. The influence of age and sex on reasons for seeking and expected benefits of skin cancer screening. Arch Dermatol. 2010;146(10):1097-102. doi:10.1001/archdermatol.2010.254.

24. Ghani WMN, Doss JG, Jamaluddin M, Kamaruzaman D, Zain RB. Oral cancer awareness and its determinants among a selected Malaysian population. Asian Pac J Cancer Prev. 2013;14:1957-63.

25. Nemoto RP, Victorino AA, Pessoa GB, Cunha LLG, Silva JAR, Kanda JL, Matos LL. Oral cancer preventive campaigns: are we reaching the real target? Brazilian Journal of Otorhinolaryngology. 2015;81(1):44-9. doi:10.1016/j.bjorl.2014.03.002

\section{Submit your next manuscript to BioMed Central and we will help you at every step:}

- We accept pre-submission inquiries

- Our selector tool helps you to find the most relevant journal

- We provide round the clock customer support

- Convenient online submission

- Thorough peer review

- Inclusion in PubMed and all major indexing services

- Maximum visibility for your research

Submit your manuscript at www.biomedcentral.com/submit

) Biomed Central 